\title{
Nutritional and Health Status Evaluation of Tribes of Uttar Pradesh: An Anthropological Dimension
}

\author{
Ajeet Jaiswal* \\ Department of Anthropology, Pondicherry University, India
}

Submission: August 11, 2018; Published: August 30, 2018

*Corresponding author: Ajeet Jaiswal, Assistant Professor, Department of Anthropology, Pondicherry University, Puducherry, India, Tel: 09791201427; 08122594335; Email: rpgajeet@gmail.com

\begin{abstract}
Man needs a wide range of nutrients to lead a healthy and active life and these are derived through the diet they consume daily. Good nutrition is a basic component of health. Health and nutritional status of an individual depends on the food he eats. This paper deals with the utility of various anthropometric cut-off points in the evaluation of nutritional \& Health status. The Kharwar is one of the Adavasi groups of Uttar Pradesh and Bihar. They are contemporary of Mundari speaking Indian tribes. Racially they belong to Proto-Australoids and linguistically to Dravidian group. The traditional economic activities of the Kharwar have been agriculture and other wage earning labour. The present study is to investigate the nutritional status of adult tribals of Kharwar group. This cross-sectional study was undertaken to determine the prevalence of undernutrition using body mass index (BMI) among 18 years and above Kharwar adults of Uttar Pradesh, India. A total of 151 (75 males and 76 females) adult from different villages of Varanasi District were measured. Result revealed that prevalence of undernutrition (age and sex combined) among Kharwar was $26.5 \%$. The sex specific rates were $33.3 \%$ and $19.4 \%$ among females and males, respectively. There was a highly significant sex difference in CED prevalence based on BMI. Kharwar adults were experiencing high (serious) situation for all age groups and the women and oldest among them were experiencing the most serious situation with respect to their health and nutritional status.
\end{abstract}

Keywords: Chronic Energy Deficiency; Kharwar tribes; Nutritional Profile; Body Mass Index; Dense forest; Community; Malnourishment; Proteins; Carbohydrates; Minerals; Morbidity; Mortality; Food scarcity; Height; Waist circumference

\section{Introduction}

Table 1: Distribution of Kharwar tribes according to Age group.

\begin{tabular}{|c|c|c|c|c|}
\hline \multirow{2}{*}{$\begin{array}{c}\text { Age Group } \\
\text { (Yrs) }\end{array}$} & \multicolumn{4}{|c|}{ Kharwar tribes (151) } \\
\cline { 2 - 5 } & No. & Male & Female & \% \\
\hline $18-39$ & 87 & 43 & 44 & 57.62 \\
\hline $40-59$ & 44 & 22 & 22 & 29.12 \\
\hline$\geq 60$ & 20 & 10 & 10 & 13.26 \\
\hline
\end{tabular}

India has a variety of tribal population reflecting its great ethnic diversity. They constitute about $8.2 \%$ of total population, though they are scattered all over the hilly and dense forest regions of the country. Nutrition is the basics for the survival of an individual. It is not just confined with the intake of nutrients but also the utilization for proper growth and development of the body. Nutritional status grossly depends upon the feeding habits, ecology, vegetation of the area and the socioeconomic condition of the community. India, in recent years has become self-sufficient from the agricultural point of view, but the problem of malnutrition continues undoubtedly, and it is still considered to be one of the crucial issues. According to Calder \& Jackson [1] undernutrition is one of the major causes of morbidity and mortality in the developing world (Table 1). Inadequate dietary intake and disease are immediate causes of malnutrition and they reinforce one another synergistically.
Malnourishment may increase income inequality, lower social returns to educational expenditure, impede economic growth and increase unemployment. Epidemiological data show that the world's populations living under low socio-economic conditions and high rates of parasitic diseases are also those that have most of the world's malnutrition [2]. Nutrition plays a major role in human adaptation because it acts both as an independent stress (e.g. food scarcity) that may necessitate adjustment and as an important modifier of other stresses (e.g. disease severity). Good nutrition promotes the production and activities of growth hormones, which influences the metabolism of proteins, carbohydrates, fats and mineral and promotes nitrogen retention. Tribals who constitute $8.2 \%$ of India's population are drawing the attention of planners and administrators and are given priority in developmental measures [3]. Assessment of nutritional status is considered as a measure of health and it is necessary for planners to understand the food and nutrition situation among tribal population for upliftment of these vulnerable groups. There is very little information available regarding the diet and nutritional status of Kharwar. Hence to fill up some of this knowledge gap, the present study was carried out to assess the health and nutritional status of the kharwar. This information will be useful in the formulation of suitable development programmes like "food for work" or 
other development programmes for the nutritional upliftment of this tribe. Therefore, the objective of the present study was to evaluate the nutritional status of the adult Kharwar tribe of Varanasi- Mirzapur District of Uttar Pradesh, India.

\section{Materials and Methods}

The present study is cross-sectional and was conducted among 151 adult Kharwar tribe of Varanasi- Mirzapur District of Uttar Pradesh. The Kharwar is one of the Adavasi groups of Uttar Pradesh and Bihar. They are contemporary of Mundari speaking Indian tribes. Racially they belong to Proto-Australoids and linguistically to Dravidian group. The traditional economic activities of the Kharwar have been agriculture and other wage earning labour. They are contemporary of Mundari speaking Indian tribes. Racially they belong to Proto-Australoids and linguistically to Dravidian group. The Kharwar villages are found in comparatively plain areas. They erect their houses with mud, wood, bamboo and tiles. The traditional economic activities of the Kharwar have been agriculture and other wage earning labour.

A total of 75 males and 76 females were measured. Adults were grouped into three age group to observe the age-trend in their anthropometric measures as well the age group wise nutritional status. In the present study Kharwar of age from 18 to 80 years (both males and females) were included. Data were collected during December-January 2011-12. There were 57.6\% subject belongs to 18-39 years age group followed by $29.12 \%$ and $13.26 \%$ Kharwar people belongs to $40-59$ and $\geq 60$ years age group respectively.

Several anthropometric measurements like Weight (Wt), height $(\mathrm{Ht})$, circumferences and skinfolds were measured using the standard methodology of Weiner \& Lourie (1981) Lohman et al. [4,5] and BMI was computed using standard equation. Technical errors of measurements (TEM) were within acceptable limits. For ethical issue, both written and oral consent were obtained from each subject before commencement of the study. Nutritional status was evaluated using internationally accepted BMI guidelines [6].

Researcher followed the World Health Organization's classification (1995) of the public health problem of low BMI, based on adult populations worldwide. This classification categorizes prevalence according to percentage of a population with $\mathrm{BMI}<18.5$. Student's t-tests were performed to test for sex differences in mean values. Age-group difference was performed by ANOVA ( $F$ test). Sex differences in CED were determined by chi-square $(\chi 2)$ test. All statistical analyses were undertaken using the Statistical Package (SPSS-16). Statistical significance was set at $\mathrm{p}<0.05$.

\section{Results}

The above Tables $2 \& 3$ shows the Mean, standard deviation, t-test, ANOVA (F) and significance (p) of anthropometric measurements of adult Kharwar tribes based on of Age groupwise and, Sexwise like weight $(\mathrm{kg})$, height $(\mathrm{cm})$, midupper arm circumference $(\mathrm{cm})$, waist circumference $(\mathrm{cm})$, hip circumference $(\mathrm{cm})$, biceps skinfold $(\mathrm{mm})$, triceps skinfold $(\mathrm{mm})$, sub-scapular skinfold $(\mathrm{mm})$ and BMI $\left(\mathrm{kg} / \mathrm{m}^{2}\right)$ of more than 18 years old Kharwar tribals are presented in Table 4. Significant $(\mathrm{p}<0.001)$ sex differences in mean Weight $(\mathrm{t}=3.63, \mathrm{p}<0.001)$ and Height $(t=6.03, p<0.001)$ were observed. Marked trend (Table 5) in Height, Waist Circumference, Hip Circumference and Biceps skinfold with increasing age-group among females; marked decline in Height, Mid Upper Arm Circumference, Waist Circumference and Hip Circumference among males and Triceps skinfold and Sub-scapular skinfold among females with increasing age-group; marked increase then decrease in mean values of Weight, Biceps skinfold, Triceps skinfold, Sub-scapular skinfold \& Body Mass Index (BMI) among males and Weight, Mid Upper Arm Circumference and BMI among females with increasing age-group were observed. Significant sex difference in mean weight $(\mathrm{t}=3.56, \mathrm{p}<0.001)$ in $18-39$ and $(\mathrm{t}=2.24, \mathrm{p}<0.05)$ in (40-59) years age group, in mean height $(t=5.35, p<0.001)$ in $18-39 \&(t=2.60, p<0.01)$ in $40-59$ years age group, in mean Mid Upper Arm Circumference $(\mathrm{t}=2.57, \mathrm{p}<0.01)$ in $18-39$ years age group were observed. Results of ANOVA revealed significant $(p<0.05)$ differences in Triceps skinfold, Sub-scapular skinfold and BMI.

Table 2: Nutritional status was evaluated using internationally accepted BMI guidelines.

\begin{tabular}{|c|c|}
\hline \multirow{2}{*}{ CED BMI $=<18.5$} & CED III $=<16.0 \mathrm{~kg} / \mathrm{m}^{2}$ \\
\cline { 2 - 2 } & CED II $=16.0-16.9 \mathrm{~kg} / \mathrm{m}^{2}$ \\
\cline { 2 - 2 } & CED I $=17.0-18.4 \mathrm{~kg} / \mathrm{m}^{2}$ \\
\hline Normal: BMI $=18.5-24.9 \mathrm{~kg} / \mathrm{m}^{2}$ \\
\hline Overweight: $\mathrm{BMI} \geq 25.0 \mathrm{~kg} / \mathrm{m}^{2}$ \\
\hline
\end{tabular}

Table 3: Student's t-tests were performed to test for sex differences in mean values.

\begin{tabular}{|c|c|}
\hline Low $(5-9 \%):$ & Warning sign, monitoring required. \\
\hline Medium $(10-19 \%):$ & poor situation \\
\hline High $(20-39 \%):$ & serious situation \\
\hline Very high $(\geq 40 \%):$ & critical situation \\
\hline
\end{tabular}

Table 4: Sex wise distribution of anthropometric measurements of adult Kharwar tribes based on Mean (SD) and t-test with significance (p).

\begin{tabular}{|c|c|c|c|c|}
\hline \multirow{3}{*}{ Variables } & \multicolumn{2}{|c|}{ Sex } & \multirow{3}{*}{ t-test } & \multirow{3}{*}{ p } \\
\hline & Male & Female & & \\
\hline & Mean \pm SD & Mean \pm SD & & \\
\hline Age & $38.90 \pm 16.80$ & $37.90 \pm 16.678$ & 0.38 & 0.687 \\
\hline Weight & $48.98 \pm 6.53$ & $45.00 \pm 7.55$ & 3.63 & 0.000 \\
\hline Height & $152.81 \pm 6.51$ & $148.82 \pm 4.46$ & 6.03 & 0.000 \\
\hline $\begin{array}{l}\text { Mid Upper Arm } \\
\text { Circum. }\end{array}$ & $24.85 \pm 2.53$ & $24.42 \pm 5.67$ & 1.93 & 0.057 \\
\hline $\begin{array}{c}\text { Waist } \\
\text { Circumference }\end{array}$ & $71.20 \pm 5.46$ & $70.99 \pm 6.10$ & 0.23 & 0.724 \\
\hline
\end{tabular}




\section{Global Journal of Archaeology \& Anthropology}

\begin{tabular}{|c|c|c|c|c|}
\hline $\begin{array}{c}\text { Hip } \\
\text { Circumference }\end{array}$ & $80.68 \pm 4.61$ & $80.83 \pm 6.41$ & -0.07 & 0.838 \\
\hline Biceps skinfold & $3.90 \pm 079$ & $3.43 \pm 0.45$ & 1.28 & 0.188 \\
\hline Triceps skinfold & $4.96 \pm 1.01$ & $4.53 \pm 1.25$ & -0.01 & 0.986 \\
\hline $\begin{array}{c}\text { Sub-scapular } \\
\text { skinfold }\end{array}$ & $5.95 \pm 1.21$ & $5.42 \pm 1.55$ & 0.18 & 0.873 \\
\hline BMI & $21.50 \pm 2.81$ & $20.49 \pm 3.40$ & 0.58 & 0.561 \\
\hline
\end{tabular}

The above Table 5 shows age group and sex wise distribution of prevalence of CED (\%) based on BMI $\left(\mathrm{kg} / \mathrm{m}^{2}\right)$ among adult Table 5: Age group and Sex wise distribution of anthropometric measurements of adult Kharwar tribes based on mean (SD), t-test and ANOVA

$(F)$ with significance $(p)$.

\begin{tabular}{|c|c|c|c|c|c|c|}
\hline \multirow{2}{*}{ Variables } & \multirow{2}{*}{ Sex \& t-test } & \multicolumn{3}{|c|}{ Age-group (Years) Mean (SD) } & \multirow{2}{*}{ ANOVA (F) } & \multirow{2}{*}{ significance $(p)$} \\
\hline & & 18-39 & $40-59$ & $\geq 60$ & & \\
\hline \multirow{3}{*}{ Weight } & Male & $49.28 \pm 5.35$ & $51.24 \pm 6.73$ & $44.78 \pm 6.78$ & 3.28 & 0.04 \\
\hline & Female & $44.62 \pm 6.58$ & $45.49 \pm 8.64$ & $45.45 \pm 1.72$ & 0.15 & 0.87 \\
\hline & t-test & $3.56^{* * *}$ & $2.25^{*}$ & 0.23 & - & - \\
\hline \multirow{3}{*}{ Height } & Male & $155.44 \pm 5.49$ & $153.44 \pm 6.45$ & $152.42 \pm 5.55$ & 1.16 & 0.32 \\
\hline & Female & $148.43 \pm 6.22$ & $148.62 \pm 8.69$ & $149.59 \pm 2.29$ & 0.14 & 0.87 \\
\hline & t-test & $5.35^{* * *}$ & $2.60^{* *}$ & 1.13 & & \\
\hline \multirow{3}{*}{$\begin{array}{l}\text { Mid Upper Arm } \\
\text { Circumfere }\end{array}$} & Male & $25.59 \pm 2.13$ & $25.34 \pm 3.13$ & $25.11 \pm 3.03$ & 0.54 & 0.58 \\
\hline & Female & $24.28 \pm 3.36$ & $25.43 \pm 4.36$ & $25.20 \pm 2.45$ & 0.75 & 0.47 \\
\hline & t-test & $2.57^{* *}$ & 0.10 & -0.07 & & \\
\hline \multirow{3}{*}{$\begin{array}{l}\text { Waist Circumfere- } \\
\text { nce }\end{array}$} & Male & $72.39 \pm 5.03$ & $72.24 \pm 5.77$ & $68.16 \pm 6.67$ & 2.69 & 0.07 \\
\hline & Female & $71.13 \pm 6.28$ & $72.13 \pm 6.44$ & $74.20 \pm 5.34$ & 0.99 & 0.37 \\
\hline & t-test & 1.29 & 0.07 & 0.94 & & \\
\hline \multirow{3}{*}{$\begin{array}{l}\text { Hip Circumfere- } \\
\text { nce }\end{array}$} & Male & $82.38 \pm 4.23$ & $81.33 \pm 5.12$ & $79.37 \pm 4.82$ & 1.64 & 0.20 \\
\hline & Female & $80.76 \pm 4.85$ & $82.38 \pm 5.83$ & $84.38 \pm 5.43$ & 1.79 & 0.17 \\
\hline & t-test & 1.54 & -0.74 & -1.89 & & \\
\hline \multirow{3}{*}{ Biceps skinfold } & Male & $3.35 \pm 0.85$ & $3.71 \pm 0.40$ & $2.99 \pm 0.42$ & 2.89 & 0.06 \\
\hline & Female & $3.23 \pm 0.70$ & $3.26 \pm 0.84$ & $3.38 \pm 0.87$ & 0.16 & 0.85 \\
\hline & t-test & 0.79 & 1.93 & -1.11 & & \\
\hline \multirow{3}{*}{ Triceps skinfold } & Male & $4.25 \pm 1.22$ & $4.75 \pm 0.72$ & $3.71 \pm 0.42$ & 4.46 & 0.01 \\
\hline & Female & $4.37 \pm 1.13$ & $4.36 \pm 1.55$ & $4.15 \pm 0.76$ & 0.12 & 0.88 \\
\hline & t-test & -0.51 & 1.15 & -1.54 & & \\
\hline \multirow{3}{*}{$\begin{array}{l}\text { Sub-scapular } \\
\text { skinfold }\end{array}$} & Male & $5.43 \pm 1.33$ & $5.92 \pm 1.24$ & $4.58 \pm 0.78$ & 4.28 & 0.02 \\
\hline & Female & $5.46 \pm 1.41$ & $5.45 \pm 1.90$ & $5.27 \pm 1.85$ & 0.06 & 0.94 \\
\hline & t-test & -0.08 & 1.03 & -1.03 & & \\
\hline \multirow{3}{*}{ BMI } & Male & $20.38 \pm 2.32$ & $21.75 \pm 3.84$ & $18.99 \pm 2.96$ & 3.57 & 0.03 \\
\hline & Female & $20.25 \pm 3.34$ & $20.48 \pm 3.41$ & $20.28 \pm 3.55$ & 0.04 & 0.96 \\
\hline & t-test & 0.23 & 1.25 & -0.82 & & \\
\hline
\end{tabular}

\section{Discussion}

India has a large and diverse tribal population. Scheduled Tribe people constitute about less than $9 \%$ of the total population in India, with varying proportions in different States. They live in unique physical, socio-economic and cultural environment, isolated from general population. In view of their habitat and food habits, they form a distinct group compared to other populations. Their food intake is influenced by vagaries of nature, with large seasonal variations, depending upon availability of agricultural
Kharwar tribes. Result revealed that prevalence of undernutrition (CED grades age and sex combined) among Kharwar was 27.05 $\%$. The sex specific rates were $32.5 \%$ and $21.6 \%$, among females and males, respectively. It was also observed that young adult females (18-39 years) had the highest prevalence of CED (36.6\%) followed by elderly males and females (33.5\%) i.e $\geq 60$ years age group, females of age group 40-59 (27.5\%), males of age group 18-39 (21.5\%) and males of age group 40-59 (9.8\%), respectively. There was a highly significant sex difference in CED prevalence based on BMI $\left(\chi^{2}=10.34, \mathrm{df}=4, \mathrm{p}=0.05\right)$. 


\section{Global Journal of Archaeology \& Anthropology}

Birhors [10] and Kharwar (present study) have the highest mean BMI (more than $20.0 \mathrm{~kg} / \mathrm{m}^{2}$ ) followed by Santal (20.0) [11]; Dhimal [12], Lodha [13], Lodha [14] and Santal [9] (19.5); Oraon (18.8) [15]; Bhumij [16], Kora Mudi [17], Munda [18] and Bhumij (18.7) [13]; Kora Mudi (18.6) [19] and least mean BMI was observed among the Santal $\left(18.5 \mathrm{~kg} / \mathrm{m}^{2}\right)$ males of North India.
Similarly, Kharwar (present study) females have the highest mean BMI (20.5 kg/m²) followed by Birhors, Oraon (19.7) [14]; Santal (19.5) [9]; Lodha [12] and Santal (19.3); Dhimal (19.1); Santal (18.7); Bhumij (18.4) [20]; Kora Mudi (18.3); Santal (18.1) and the least among them was observed among Munda (17.7) females of North India (Table 7).

Table 6: Age group and Sex wise distribution of prevalence of CED (\%) based on BMI $\left(\mathrm{kg} / \mathrm{m}^{2}\right)$ among adult Kharwar tribes.

\begin{tabular}{|c|c|c|c|c|c|c|}
\hline Nutritional & \multicolumn{6}{|c|}{ Sex } \\
\hline \multirow{3}{*}{ Status } & \multicolumn{3}{|c|}{ Male $(\mathrm{N}=75)$} & \multicolumn{3}{|c|}{ Female(N=76) } \\
\hline & 18-39 & $40-59$ & $\geq 60$ & $18-39$ & 40- 59 & $\geq 60$ \\
\hline & $(n=43)$ & $(n=22)$ & $(n=10)$ & $(n=44)$ & $(n=22)$ & $(n=10)$ \\
\hline CED III & 1.5 & 4.7 & 11.2 & 4.6 & 9.2 & 11.2 \\
\hline CED II & 0.5 & 0.5 & 0.5 & 13.7 & 4.6 & 0.5 \\
\hline CED I & 19.5 & 4.6 & 21.8 & 18.3 & 13.7 & 21.8 \\
\hline Overall CED & 21.5 & 9.8 & 33.5 & 36.6 & 27.5 & 33.5 \\
\hline Normal & 76.0 & 75.8 & 65.9 & 54.2 & 63.3 & 55.3 \\
\hline Overweight & 2.5 & 14.4 & 0.6 & 9.2 & 9.2 & 11.2 \\
\hline
\end{tabular}

Table 7: Sex wise and overall comparison of mean BMI $\left(\mathrm{kg} / \mathrm{m}^{2}\right)$ and prevalence of CED of the Kharwar tribe with some of the tribal population of North India.

\begin{tabular}{|c|c|c|c|c|c|}
\hline Community & Male & Female & Overall Mean & CED (\%) & Reference \\
\hline Bhumij & 18.7 & 18.4 & 18.6 & 53.7 & Ghosh [20] \\
\hline Dhimal & 19.5 & 19.1 & 19.3 & 36.7 & Banik et al. [12] \\
\hline Kora Mudi & 18.7 & 18.3 & 18.5 & 52.2 & Bose et al. [17] \\
\hline Kora Mudi & 18.6 & 18.3 & 18.5 & 53.5 & Bisai et al. [19] \\
\hline Lodha & 19.5 & 19.3 & 19.4 & 43.0 & Mondal [13] \\
\hline Munda & 18.7 & 17.7 & 18.2 & 58.5 & Ghosh \& Bharati [18] \\
\hline Oraon & 18.8 & 19.7 & 19.3 & 39.4 & Mittal \& Sivastava [15] \\
\hline Santal & 20.0 & 19.3 & 19.7 & 31.6 & Bose et al. [17] \\
\hline Santal & 18.5 & 18.7 & 18.6 & 53.7 & Ghosh \& Malik [16] \\
\hline Santal & 20.5 & 19.5 & 20.0 & 34.5 & Mukhopadhyay [9] \\
\hline Lodha & 19.5 & -- & -- & 45.2 & Bose et al. [14] \\
\hline Bhumij & 18.7 & -- & -- & 48.4 & Bose et al. [14] \\
\hline Santal & 19.5 & 18.1 & 18.8 & 46.7 & Das \& Bose [10] \\
\hline Birhor & 20.5 & 20.2 & 20.3 & 26.5 & Das et al. (2013) \\
\hline Kharwar & 21.6 & 20.5 & 21.05 & 27.05 & Present study \\
\hline
\end{tabular}

In general, prevalence of CED among the tribals of North India shows that the overall CED was highest among the Mundas (58.5\%) of Kolkata followed by Bhumij and Santal (53.7\% by Ghosh [20]); Kora Mudi (53.5 \% by Bisai et al., 2008); Kora Mudi; Bhumij (48.4 \% by Bose et al., [14]); Santal (46.7 \% by Das and Bose, 2010); Lodha (45.2\% by Bose et al., 2008); Lodha (43.0 $\%$ by Mondal, 2007); Oraon (39.4 \% by Mittal and Srivastava, 2006); Dhimal (36.7 \% by Banik et al. [12]); Santal (34.5\% by Mukhopadhyay [9]); Santal (31.6\% by Bose et al., 2006), Birhor (26.5\% by Das et al. 2013) and the present study Kharwar $(27.05 \%)$ had the least prevalence of CED among the other studied tribal community of North India.

According to National Family Health Statistics- 3 report (NFHS-3, 2005-2006), the prevalence of undernutrition in India is $33.0 \%$ among males and $28.1 \%$ among females. In urban areas, these figures were $19.8 \%$ and $17.5 \%$, respectively. In rural areas these were $38.8 \%$ and $33.1 \%$, respectively. However, the situation is much worse in North India especially Uttar Pradesh and Bihar with corresponding prevalence of $37.7 \%$ and $31.6 \%$, respectively. Among urban males and females, they were $19.9 \%$ and $15.5 \%$, respectively. The corresponding rural figures were $44.9 \%$ (males) and $38.0 \%$ (females). Therefore, the use of BMI and WHO [6] BMI based cut-off points for the evaluation of CED are valid for use among tribal populations of India.

The primary importance, from the public health perspective is the need for immediate nutritional intervention programs to be implemented among Kharwar tribes of Varanasi-Mirzapur district of Uttar Pradesh and all other tribal groups experiencing 
nutritional stress. The Government should play an active role in reducing the rates of undernutrition among tribal people. It is imperative that the recommendations should include not only adequate dietary intake but also various ways in which they can enhance their socio-economic status through improved education and employment opportunities. It has already been emphasized [21-24] that there exists variation in social and economic conditions among tribes of India. Similar studies should also be undertaken among all other tribal populations in India since they constitute a sizeable portion of India's population.

\section{Conclusion}

From our study it can be concluded that the nutritional status of Kharwar tribes was serious; females and oldest peoples experiencing the most severe situation then the others. There is strong evidence that, in general, Kharwar tribes and other tribal populations of India were experiencing serious to critical nutritional stress.

\section{Acknowledgement}

Author gratefully acknowledged Kharwar tribes and their family member, villagers and block authorities of VaranasiMirzapur district of Uttar Pradesh for their cooperation. Author would also like to thank Anil Khadanga and Jyoti Raja (student of Department of Anthropology, Pondicherry University) for their help in data collection and especially grateful for the assistance and encouragement of Prof. A.K. Kapoor and Prof. Satwanti Kapoor and the medical professional of BHU for their help during research.

\section{References}

1. Calder PC, Jackson AA (2000) Undernutrition, infection and immune function. Nutrition Research Review 13(1): 3-29.

2. Crompton DWT, Nesheim MC (1982) Nutritional science and parasitology: A case for collaboration. Bioscience 32: 677-680.

3. Census of India 2001 and 2011.

4. Weiner JS, Lourie JA (1981) Human Biology: A Guide to Field Methods. International Biological Programme, IBP No.9. Marylebone London NW, UK.

5. Lohman TG, Roche AF, Martorell R (1988) Anthropometric Standardization Reference Manual. Human Kinetics Books, Chicago, USA.

6. WHO (1995) Physical Status: The Use and Interpretation of Anthropometry. Technical Report Series no. 854. World Health Organization, Geneva, Switzerland, USA.

7. Rao HD, Brahmam GNV, Rao MK, Reddy GCH, Rao PN (1996) Nutrition profile of certain Indian Tribes. Proceedings of a National seminar on Tribal Development options. PK Samal, edt GB Pant. Institute of Himalayan Environment \& Development, Almora, India.

8. Rao HD, Rao MK, Rao RG (1994) Nutritional status of Tribal preschool children in three ecological zones of Madhya Pradesh. Indian Pediatrics 31(6): 635-640.
9. Mukhopadhyay A (2009) Anthropometric characteristics and undernutrition among adult Santal tribe of Birbhum District. West Bengal, Anthropological Science, India, p. 1-4.

10. Das S, Bose k (2010) Body Mass Index and Chronic Energy Deficiency among Adult Santals of Purulia District, West Bengal, India. International Journal of Human Science 7: 2.

11. Bose K, Banerjee S, Bisai S, Mukhopadhyay A, Bhadra (2006) Anthropometric profile and chronic energy deficiency among adult Santal tribals of Jhargram, West Bengal, India: Comparison with other tribal populations of Eastern India. Ecology of Food Nutrition 45: I-II.

12. Banik DS, Bose K, Bisai S, Bhattacharya M, Das S (2007) Chronic energy deficiency among adult Dhimals of Naxalbari, West Bengal: Comparison with other tribes of Eastern India. Food and Nutrition Bulletine 28(3): 348-352.

13. Mondal PS (2007) Nutritional status of adult Lodha males of Shyamraipur, Paschim Medinipur. Paper presented in seminar on Approaching Development in Department of Anthropology, Vidyasagar University, India, p. 6.

14. Bose K, Bisai S, Mondal PS, Ghosh M (2008) Body mass index and chronic energy deficiency among adult male Lodhas and Bhumijs: A comparison with other tribal populations of West Bengal, India. Journal of Public Health. 16: 117-121.

15. Mittal PC, Srivastava S (2006) Diet, nutritional status and food related traditions of Oraon tribes of New Mal (West Bengal), India. Rural and Remote Health 6(1): 385.

16. Ghosh S, Malik SL (2007) Sex Differences in Body Size and Shape among Santhal of West Bengal. Anthropologist 9(2): 143-149.

17. Bose K, Ganguli S, Mamtaz H, Mukhopadhyay A, Bhadra M (2006) High prevalence of undernutrition among adult Kora Mudi tribals of Bankura District, West Bengal, India. Anthropological Science 114: 6568.

18. Ghosh R, Bharati P (2006) Nutritional status of adults among Munda and Pod populations in a peri urban area of Kolkata City, India. Asia Pacific Journal of Public Health 18(2): 12-20.

19. Bisai S, Bose K, Katun A, Ganguli S, Das P (2008) Nutritional stress in Kora Mudis of two districts in West Bengal. India: A comparative statement. In: Basu SK, Banik SD (Eds.), Enviroment Pollution, Protection and Policy Issues. APH Publication Corporation, New Delhi, India.

20. Ghosh M (2007) Nutritional status of adult Bhumij males of Kharagpur, Paschim Medinipur. Paper presented in seminar on Approaching Development in Department of Anthropology. Vidyasagar University, India, 5: 22.

21. Topal YS, Samal PK (2001) Causes for variation in social and economic conditions among tribes of Indian Central Himalaya: A comparative study. Man, in India. 81: 87-88.

22. Mandal H, Mukherjee S, Datta A (2002) India- An Illustrated Atlas of Tribal World. Anthropological Survey of India, Kolkata, India.

23. National Family Health Survey (NFHS-3) (2006) Report on West Bengal by International Institute for Population Science (IIPS), India. Volume II, Mumbai, IIPS.

24. Scrimshaw NS, Taylor CE, Gordon JE (1968) Interaction of Nutrition and Infection. WHO, Genev, Switzerland, USA. 
Your next submission with Juniper Publishers will reach you the below assets

- Quality Editorial service

- Swift Peer Review

- Reprints availability

- E-prints Service

- Manuscript Podcast for convenient understanding

- Global attainment for your research

- Manuscript accessibility in different formats

( Pdf, E-pub, Full Text, Audio)

- Unceasing customer service

Track the below URL for one-step submission https://juniperpublishers.com/online-submission.php 